\title{
Gastric Plexiform Fibromyxoma
}

National Cancer Institute

\section{Source}

National Cancer Institute. Gastric Plexiform Fibromyxoma. NCI Thesaurus. Code C95902.

A rare soft tissue neoplasm arising from the stomach. It occurs in the antrum and pyloric region and it may extend into the duodenum. It occurs in all ages and affects men and women equally. Morphologically it is characterized by a multinodular plexiform mass that involves the muscular layer. The neoplastic cells are spindle-shaped and the mitotic activity is low. It follows a benign clinical course. 